\title{
Time- and sample-dependent differences in polyomavirus incidence following hematopoietic stem cell transplantation
}

\author{
Alexey B. Chukhlovin ${ }^{1}$, Yury A. Eismont ${ }^{2}$, Vladimir N. Vavilov ${ }^{1}$, Ludmilla S. Zubarovskaya ${ }^{1}$, Boris V. Afanasyev ${ }^{1}$ \\ ${ }^{1}$ R. M. Gorbacheva Memorial Institute of Children Oncology, Hematology and Transplantology, and ${ }^{2}$ Department of Clinical \\ Microbiology, The $1^{\text {st }}$ St.Petersburg State I. Pavlov Medical University, St. Petersburg, Russian Federation
}

Prof. Dr. Alexey B. Chukhlovin, Department of Clinical Laboratory Diagnostics and Molecular Medicine, ${ }^{1} \mathrm{R}$. M. Gorbacheva Memorial Institute of Children Oncology, Hematology and Transplantology, The $1^{\text {st }}$ St.Petersburg State I. Pavlov Medical University, L. Tolstoy St 6/8, 197089, St. Petersburg, Russian Federation
Phone: +7 (921) 3250094 (mob.); +7 (812) 338 7079,

E-mail: alexei.chukh@mail.ru

\section{Summary}

Introduction. Latent polyomaviruses are frequently activated after hematopoietic stem cell transplantation (HSCT). E.g., BK virus (BKV) infection is associated with hemorrhagic cystitis, whereas JC virus (JCV) may affect brain and other tissues. Time course of the polyomavirus activation after HSCT is poorly understood. Hence, the aim of our study was to compare age- and time dependence of BKV and JCV incidence in various clinical specimens taken from HSCT patients. Patients and Methods. We have observed 87 oncohematological patients (1 to 60 years old) subjected to allogeneic HSCT. Myeloablative conditioning was applied in $42 \%$ of cases. The patients received pre-emptive acyclovir treatment and immunosuppressive therapy with cyclosporin A. $\mathrm{BKV}, \mathrm{JCV}$, and cytomegalovirus (CMV) were assayed biweekly in blood leukocytes and urine cells, and, if indicated, in cerebrospinal fluid (CSF), or bronchoalveolar lavage (BAL), by means of gene-specific PCR. Results.
Overall BKV detection rates in leukocytes, urine, CSF, and BAL were, respectively, $31 \%$ and $72 \%, 16 \%$, and $21 \%$. Appropriate prevalence rates for JC were $16 \%, 36 \%, 2 \%$, and $19 \%$. Strong correlations existed between BKV, JCV, and CMV positive tests in the samples. BKV prevalence in urine was increased with patients' age. Higher BKV incidence in urine was noted at 2-3 months after HSCT. JC frequency in urine peaked at 1-3 months, as well as in BAL samples at 3-4 months post-transplant.

\section{Conclusion}

PCR positivity for BKV and JCV depends on patients' age and time post-transplant, with maximal positivity rates for urinary cell sediments.

\section{Keywords}

Hematopoietic stem cell transplantation; BK virus, JC virus, activation, time dependence.

\section{Introduction}

Both latent and overt polyomavirus infections are widely spread in human population [3]. Specifically, BK virus (BKV) is commonly detected in urine, blood leukocytes and plasma of the patients after renal transplantation, followed in some cases by clinically sound polyomavirus nephropathy [12].

Polyomaviruses are also activated following hematopoietic stem cell transplantation (HSCT), due to immune deficiency caused by transient hematopoietic aplasia and immunosup- 
pressive treatment. E. g., BKV infection is associated with hemorrhagic cystitis in transplanted patients [13], whereas JC virus (JCV) positivity may be connected with increased risk of multifocal encephalopathy [2]. Moreover, some other cells and tissues bear specific receptors for JCV, thus providing additional targets for this pathogen [5].

Hence, the aim of our study was to evaluate time-dependent changes in BKV and JCV positivity in different clinical specimens in the patients undergoing HSCT procedure.

\section{Materials and methods}

\section{Patients}

From 2010 to 2013, we observed 87 patients (1 to 60 years old) with various hematological disorders including acute lymphoblastic leukemia (ALL, $n=44$ ), acute myeloblastic leukemia (AML, $\mathrm{n}=21$ ), myelodysplastic syndrome (MDS, $\mathrm{n}=8)$, malignant lymphomas $(\mathrm{n}=6)$, aplastic anemias $(\mathrm{n}=4)$, inherited metabolic syndromes $(n=3)$, chronic myelogenous leukemia (CML, $n=1)$. All the patients underwent allogeneic HSCT. Myeloablative conditioning regimens were applied in $42 \%$ of cases. The patients received transplants from related HLA-compatible (12\%), haploidentical (28\%), or unrelated, HLA-compatible donors (60\%). Bone marrow (BM) or peripheral blood stem cells (PBSC) were transplanted, respectively, in $52,5 \%$ and $47,5 \%$ of cases. Standard pre-emptive acyclovir treatment was administered to all patients. To prevent acute graft-versus-host disease (aGvHD), we used cyclosporin A and metothrexate.

\section{Polyomavirus DNA screening}

DNA diagnostics of BKV and JCV in blood and urine was performed bi-weekly, using qualitative gene-specific PCR. The samples were taken up to 3 months, and, if possible, until 6 months post-HSCT. Polyomavirus DNA was assayed in peripheral blood leukocytes obtained from $0,5 \mathrm{~mL}$ of whole blood by lysis and repeated centrifugation, or in urinary cell specimens. In complicated cases, appropriate local samples were tested, i. e., cell pellets from urine, cerebrospinal fluid (CSF), broncho-alveolar lavage (BAL). In such cases, polyo- mavirus assays were administered by the attending doctor, usually for suspected cystitis, respiratory, or neurological disorders. DNA isolation from the cell lysates was performed with a standard sorbent technique («DNA-Sorb», Interlabservice, Moscow). BK virus DNA (VP1 gene) was detected by means of gene specific PCR [10]. The following primers were used: sense, $5^{\prime}$ - aaa tcc att tta tct aat ata tg - 3 ' and antisense, $5^{\prime}$-ggc tta aag gag cat ga-3' (amplicon length, $372 \mathrm{bp}$ ). JCV detection was based on a test system used elsewhere (7), using the following primers: sense, 5 '-tattccaccaggattcccattc-3'. and antisense, 5'-gttcttggagacacccctaca-3' (amplicon length, $150 \mathrm{bp}$ ), purchased from Synthol, Moscow. DNA amplification was carried out in a standard master mixture with 5xPCR buffer, using Bio-Rad ICycler. CMV DNA was detected with a commercial test system (Interlabservice, Moscow).

PCR products were separated by means of electrophoresis in $2 \%$ agarose gel. Gel photographing, and identification of specific gene products was performed with "Bio-Rad" gel documentation system. Actual sensitivity of the BKV and JCV detection assays was, respectively, 100 and 200 gene copies/ $\mathrm{mL}$ of the sample, as tested with appropriate quantitative controls.

\section{Statistical methods}

Statistical evaluation of the data was performed by means of STATISTICA 6.0 software, using $\chi^{2}$ and Student criteria. Correlation quotients and their significance were determined by Spearman criterion. The differences were considered significant at $\mathrm{P}<0,05$.

\section{Results}

Overall frequency of positive BKV tests in the patients during the entire observation period was $31 \%$ for blood, $72 \%$ for urine, $16 \%$ for CSF, and $21 \%$ for BAL samples (for a total of 663 clinical specimens). Appropriate rates for JCV were, respectively, $16 \%, 36 \%, 2 \%$ и $19 \%$. As seen from these figures, $\mathrm{BKV}$ was more commonly found in urine than in other biological samples $(p<0,0001)$. JCV was also rather common in urine $(\mathrm{p}<0,0001)$, but it was quite rare in CSF cells, despite of its proposed role in brain disorders [2].

\begin{tabular}{|l|l|l|l|l|}
\hline \multirow{2}{*}{ Types of samples } & \multicolumn{2}{l|}{ Age of patients, years } \\
\cline { 2 - 5 } & $1-10$ & $11-20$ & $21-30$ & $31>$ \\
\hline BKV blood & $0,33 \pm 0,05(96)$ & $0,30 \pm 0,05(83)$ & $0,33 \pm 0,11(23)$ & $0,37 \pm 0,09(27)$ \\
\hline BKV urine & $0,61 \pm 0,09(31)$ & $0,79 \pm 0,05(75)$ & $0,87 \pm 0,06 *(31)$ & $0,89 \pm 0,06^{\star}(27)$ \\
\hline JCV blood & $0,20 \pm 0,04(97)$ & $0,16 \pm 0,04(83)$ & $0,15 \pm 0,08(20)$ & $0,23 \pm 0,08(26)$ \\
\hline$J C V$ urine & $0,28 \pm 0,08(29)$ & $0,44 \pm 0,06(71)$ & $0,32 \pm 0,09(28)$ & $0,48 \pm 0,09(27)$ \\
\hline
\end{tabular}

Total numbers of clinical samples are shown in parentheses *, difference against younger groups ( $<20$ years old) is significant by $\mathrm{p}=0,04$.

Table 1. Frequency of BKV and JCV-positive tests $(M+m)$ in blood leukocytes and urinary cells for different age groups 
In addition, there was a strong correlation between $\mathrm{BK}$ and JC virus occurrence in the samples $(r=0,29, p=0,00001)$, especially, in urinary cells. Similar correlation for urine specimens was found between JCV and cytomegalovirus positivity $(\mathrm{r}=0,28, \mathrm{p}=0,001)$

We have also studied age-dependence of BKV and JCV prevalence in blood and urine (Table 1). BKV prevalence was about $60 \%$ in younger patients, with a moderate increase with patients' age (at 30-40 years and older). Meanwhile, we did not reveal a significant age-dependent increase in JCV frequency.

As shown in Fig. 1, upon assessing post-HSCT changes of BKV prevalence in blood and urine, we have noted a sufficient increase of BKV incidence in urine, with a peak at 2 nd month (from $43 \%$ to $87 \%, \mathrm{p}<0,002$ ), thus well correlating

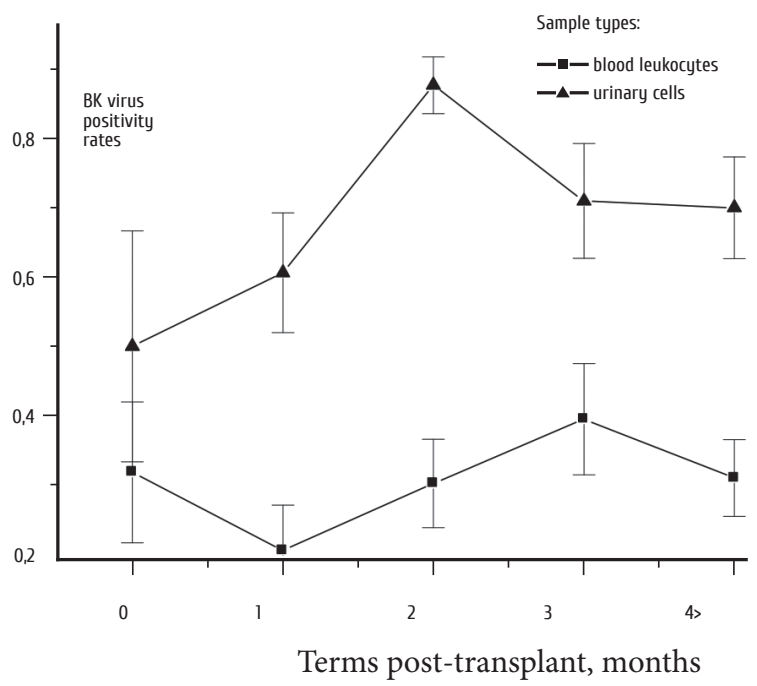

Fig. 1. Incidence of BK virus-positive tests in blood (squares) and urine (triangles) after HSCT (M+m). Abscisse: terms after transplantation, months. Ordinate, frequency of BK-positive tests.

\section{Discussion}

BK-positivity of urine seems to be a regular event in severely immunocompromised patients after HSCT, thus confirming its involvement in post-treatment cystitis and other complications. Several studies aimed for searching interrelations between BK reactivation and hemorrhagic cystitis post-HSCT $[1,14]$. Generally, BK-viruria is shown to be more common than viremia in posttransplant period. However, blood BK levels are also reported to be of a prognostic value for cystitis [8]. A study by Drew et al. [4] has shown that BK activation in patients of hemorrhagic cystitis mainly develops during the 3rd month post-HSCT, with even higher viral loads in urine than in blood plasma. In our experience, this time dynamics is replicated for the urinary samples in general group of HSCT patients. with high risk of hemorrhaghic cystitis within 100 days after HSCT.

Posttransplant changes of JCV prevalence in urine were quite similar to those of BKV dynamics (Fig.2), showing a significant increase within first months post-HSCT (from $9 \%$ be to $32-41 \%$ at $1-3$ months, $\mathrm{p}=0,04)$. Noteworthy, the JC virus frequency was shown to peak in bronchoalveolar samples at 4 to 6 months post-transplant ( 6 positives of 16 samples, as compared to $0 / 19$ at earlier terms, $\mathrm{p}=0,003)$.

We did not reveal any significant correlations between the positivity for BKV or JCV, and source of stem cell source (BM vs PBSC), and intensity of conditioning regimen. However, an increased urinary BKV incidence was noted in cases of haploidentical HSCT, as compared with HLA-compatible transplantation, respectively, $87 \%(33 / 38)$ vs. $70 \%$ (97/138), $\mathrm{p}=0,04$.

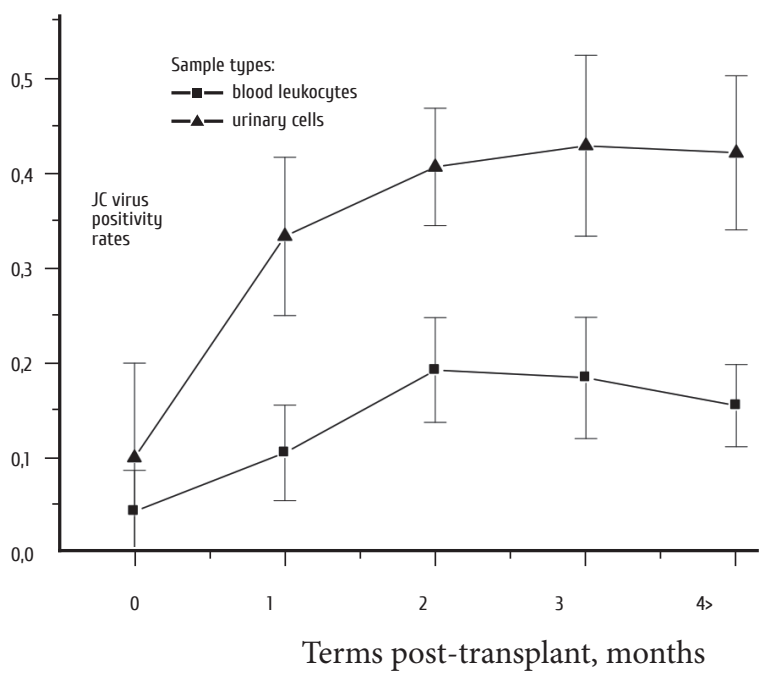

Fig. 2. Frequency of JCV-positive tests in blood (squares) and urine (triangles) after HSCT (M+m). Abscisse: terms after transplantation, months. Ordinate, frequency of JC-positive tests.

The most possible reason of post-HSCT cystitis lays in wellknown avidity of BKV for urotelium [16]. Our observation of higher BK viruria rates in haploidentical HSCT is in accordance with increased BK incidence in serum after mismatched renal transplantation [9].

Possible role of JC virus after HSCT remains less clear. E.g., it was rarely found in cerebrospinal fluid of our posttransplant patients, thus suggesting its marginal pathogenetic role in encephalopathies developing in some HSCT cases. Meanwhile, the JCV incidence is increasing in time-dependent manner both in urine (at 1-3 months post-HSCT).

Similarly, JC-positivity proved to be quite common in bronchoalveolar cells at 3-4 months after HSCT. Certainly, this finding needs confirmation with larger number of cases. However, we cannot exclude a possible involvement of JCV 
into respiratory disorders. JCV is shown to be harbored not only in urothelium, but also in other cell populations, including blood leukocytes and glial cells $[7,15]$. Interestingly, several workers have previously found JCV in lymphoid cell populations, especially, B cells [6]. One results suggest reactivation of JCV in respiratory system [5], thus corresponding to our data on JC positivity in bronchoalveolar cell populations from HSCT patients. Taking into account evident role of donor lymphoid cells in genesis of chronic GvHD [11], one may consider possible role of JC virus as a risk factor for this posttransplant disorder.

In conclusion, the mean incidence rates for the two polyomaviruses depend upon patients' age and time posttransplant, with different detection rates for distinct clinical samples. Significant correlations between BK, JC, and CMV positivity suggest similar biological mechanisms for their activation in immunosuppressed patients following HSCT.

\section{References}

1. Arai Y, Maeda T, Sugiura H, et al. Risk factors for and prognosis of hemorrhagic cystitis after allogeneic stem cell transplantation: Retrospective analysis in a single institution. Hematology 2012; 17 (4): 207-214.

2. Bellizzi A, Nardis C, Anzivino E, Rodio D, et al. Human polyomavirus JC reactivation and pathogenetic mechanisms of progressive multifocal leukoencephalopathy and cancer in the era of monoclonal antibody therapies. J Neurovirol 2012; 18 (1): 1-11.

3. Dalianis T, Hirsch HH. Human polyomaviruses in disease and cancer. Virology 2013; 437 (2): 63-72.

4. Drew RJ, Walsh A, Ni Laoi B, Conneally E, Crowley B. $B K$ virus $(B K V)$ plasma dynamics in patients with BKV-associated hemorrhagic cystitis following allogeneic stem cell transplantation. Transpl Infect Dis 2013; 15 (3): 276-282.

5. Eash S, Tavares R, Stopa EG, Robbins SH, Brossay L, Atwood WJ. Differential distribution of the JC virus receptor-type sialic acid in normal human tissues. Am J Pathol 2004; 164 (2): 419-428.

6. Gallia GL, Houff SA, Major EO, Khalili K. Review: JC virus infection of lymphocytes- revisited. J Infect Dis 1997; 176 (6): 1603-1609.
7. Gu ZY, Li Q, Si YL, Li X, Hao HJ, Song HJ. Prevalence of $\mathrm{BK}$ virus and JC virus in peripheral blood leukocytes and normal arterial walls in healthy individuals in China. J Med Virol 2003; 70(4): 600-605.

8. Haines HL, Laskin BL, Goebel J, et al. Blood, and not urine, BK viral load predicts renal outcome in children with hemorrhagic cystitis following hematopoietic stem cell transplantation. Biol Blood Marrow Transplant 2011; 17 (10): 1512-1519.

9. Hässig A, Roos M, Etter A, et al. Association of BK viremia with human leukocyte antigen mismatches and acute rejection, but not with type of calcineurin inhibitor. Transpl Infect Dis 2014; 16(1): 44-54.

10. Holman CJ, van Burik JAH, Hinrichs SH, Balfour HH,Jr. Specific detection of human BK polyomavirus in urine samples of immunocompromised patients. Clin Diagn Lab Immunol 2003; 10 (1): 66-69.

11. Kuzmina Z, Krenn K, Petkov V, et al. CD19(+)CD21(low) $B$ cells and patients at risk for NIH-defined chronic graftversus-host disease with bronchiolitis obliterans syndrome. Blood 2013; 121 (10): 1886-1895.

12. Nickeleit V, Mihatsch MJ. Polyomavirus nephropathy in native kidneys and renal allografts: an update on an escalating threat. Transpl Int 2006; 19 (12): 960-973.

13. Rorije NMG, Shea MM, Satyanarayana G, et al. BK virus disease after allogeneic stem cell transplantation: a cohort analysis. Biol Blood Marrow Transplant 2014; 20 (4): 564-570.

14. Reploeg MD, Storch GA, Clifford DB. BK virus: a clinical review. Clin Infect Dis 2001; 33 (2): 191-202.

15. Samorei IW, Schmid M, Pawlita M, Vinters HV, Diebold K, Mundt C, von Einsiedel RW. High sensitivity detection of JC-virus DNA in postmortem brain tissue by in situ PCR. J Neurovirol. 2000; 6 (1): 61-74.

16. Seemayer CA, Seemayer NH, Duermueller U, et al. BK virus large $\mathrm{T}$ and $\mathrm{VP}-1$ expression in infected human renal allografts. Nephrol Dial Transplant 2008; 23 (12): 3752-3761

17. Shin SK, Li MS, Fuerst F, et al. Oncogenic T-antigen of JC virus is present frequently in human gastric cancers. Cancer 2006; 107 (3): 481-488 


\title{
Зависимость частоты выявления полиомавирусов от типа биоматериала и сроков после трансплантации гемопоэтических стволовых клеток
}

\begin{abstract}
Алексей Б. Чухловин ${ }^{1}$, Юрий А. Эйсмонт ${ }^{2}$, Владимир Н. Вавилов ${ }^{1}$, Людмила С. Зубаровская 1, Борис В. Афанасьев ${ }^{1}$ ${ }^{1}$ НИИ детской онкологии, гематологии и трансплантологии им. Р. М. Горбачевой и ${ }^{2}$ отделение клинической микробиологии, Первый Санкт-Петербургский государственный медицинский университет им. И. П. Павлова, СанктПетербург, Россия
\end{abstract}

E-mail: alexei.chukh@mail.ru

\section{Резюме}

\section{Введение}

Латентные полиомавирусы часто активируются после трансплантации гемопоэтических стволовых клеток (ТГСК). Например, ВК-вирусная инфекция часто ассоциирована с геморрагическим циститом, тогда как вирус JC может поражать головной мозг и другие ткани. Динамика активации полиомавирусов после ТГСК недостаточно ясна. Таким образом, целью нашего исследования было сравнение возрастной и временной зависимости обнаружения вирусов ВК и ЈС в различных клинических образцах, взятых от пациентов после ТГСК. Пациенты и методы. Мы наблюдали 87 больных онкогематологического профиля от 1 до 60 лет, которым проводили аллогенную ТГСК. Миелоаблативное кондиционирование было использовано в $42 \%$ случаев. Больные получали предварительное лечении ацикловиром и иммуносупрессивную терапию циклоспорином А. Цитомегаловирус (ЦМВ), ВК и ЈС определяли каждые 2 недели в лейкоцитах крови и клетках мочи и, по показаниям, в цереброспинальной жидкости (ЦСЖ) или клетках бронхоальвеолярных смывов (БАЛ), с помощью геноспецифической ПЦР. Результаты. Общая частота выявления вируса ВК в лейкоцитах, моче, ЦСЖ и БАЛ была, соответственно, $31 \%, 72 \%, 16 \%$ и $21 \%$. Соответствующие цифры встречаемости вируса ЈС были 16\%, 36\%, 2\% и $19 \%$. Сильные корреляции выявлены отмечались между присутствием ВК, ЈС, и ЦМВ в образцах. Встречаемость вируса ВК в моче повышалась с возрастом пациентов. Повышенная частота ВК в моче отмечалась на 2-м и 3-м месяцах после ТГСК. Частота вируса ЈС в моче была максимальной на $1-3$ мес., а также в образцах БАЛ на 3-м и 4-м мес. после ТГСК. Заключение. ПЦР-позитивность по ВК и ЈС-вирусам зависит от возраста пациента и сроков после пересадки, при максимальной частоте положительных находок в клетках мочевых осадков.

\section{Ключевые слова}

Трансплантация гемопоэтических клеток, вирус ВК, вирус JC, активация, временная зависимость. 